\title{
Elevated Temperature and Durability Studies on High Strength Concrete
}

\author{
P. Rukkun Vardhan ${ }^{1}$ and T. Muralidhara $\mathrm{Rao}^{2}$ \\ ${ }^{1}$ M.Tech Student, CVR College of Engineering/Civil Engineering Department, Hyderabad, India. \\ Email: prv1484@gmail.com \\ ${ }^{2}$ Professor, CVR College of Engineering/Civil Engineering Department, Hyderabad, India. \\ Email: tmuralidhararao@gmail.com
}

\begin{abstract}
In this paper, an attempt was made to study the effect of elevated temperatures and durability studies on fifty one numbers of ten centimeter high strength concrete cubes prepared with ultrafine mineral admixture, Alccofine 1203. Trials were made with $0 \%, 5 \%, 10 \%$ and $15 \%$ replacement of cement with Alccofine. Optimum percentage of replacement of cement by Alccofine was found to be $10 \%$. The maximum compressive strength achieved was $79.93 \mathrm{MPa}$. Elevated temperature, Non-Destructive test and Durability studies were conducted. The percentage loss in weight was found to be decreased with the temperature increase from $100^{\circ} \mathrm{C}$ to $900^{\circ} \mathrm{C}$. Similar trend was observed for Compressive strength also with the temperature increase. But compressive strength was increased at $300^{\circ} \mathrm{C}$. The weight and compressive strength was increased when immersed in Sulphate solution, Chloride solution, Alkali solution and Sea water.
\end{abstract}

Index Terms: Compressive strength, Weight, Elevated Temperatures, Sulphate Attack, Chloride Attack, Alkali Attack, Sorptivity.

\section{INTRODUCTION}

\section{A. High Strength concrete(HSC)}

HSC is characterized by high compressive strength. HSC is more durable because the low water-to-cementitious materials ratio results in very low porosity. The main advantage of HSC is its high compressive strength. Other advantages include improved microstructure and homogeneity, high flexibility with the addition of fibers. Due to the high strength of the concrete, the thickness of concrete elements will be reduced, which results in materials saving and cost saving.

\section{B. Alccofine 1203}

Alccofine 1203 is a new generation slag of high glass content with high reactivity obtained through the process of controlled granulation having Ultra-fineness with optimized particle size distribution. Alccofine1203 is much finer than other hydraulic materials like cement, fly ash, silica etc. The use of Alccofine1203 leads to a reduction of the size of the crystalline compounds, particularly calcium hydroxide which results in a reduction of the thickness of the interfacial transition zone (ITZ). It also reduces the free lime $(\mathrm{CH})$ to $\mathrm{C}-\mathrm{S}-\mathrm{H}$. This, in turn, strengthens the interfacial transition zone width with $\mathrm{C}-\mathrm{S}-\mathrm{H}$ structures occupying the $\mathrm{CH}$ crystal spaces. Thus, allowing the concrete to sustain higher loads without cracking. The physical and chemical parameters are presented in Table I and Table II.
TABLE I.

PHYSICAL PARAMETERS OF ALCCOFINE1203

\begin{tabular}{|c|c|c|c|c|c|c|}
\hline $\begin{array}{c}\text { Specific } \\
\text { gravity }\end{array}$ & $\begin{array}{c}\text { Bulk } \\
\text { Density } \\
\left(\mathrm{kg} / \mathrm{m}^{3}\right)\end{array}$ & $\begin{array}{c}\text { Fineness } \\
\left(\mathrm{Cm}^{2} / \mathrm{gm}\right)\end{array}$ & $\begin{array}{c}\text { Specific } \\
\text { Gravity }\end{array}$ & \multicolumn{3}{|c|}{$\begin{array}{c}\text { Particle size } \\
\text { distribution }(\mu)\end{array}$} \\
\hline 2.9 & 680 & 12000 & 2.86 & $\mathrm{D} 10$ & $\mathrm{D} 50$ & $\mathrm{D} 90$ \\
\cline { 5 - 7 } & & & & $1-2$ & $4-5$ & $8-9$ \\
\hline
\end{tabular}

TABLE II.

Chemical Parameters of AlcCofine1203

\begin{tabular}{|c|c|c|c|c|c|c|}
\hline $\mathrm{CaO}$ & $\mathrm{Al}_{2} \mathrm{O}_{3}$ & $\mathrm{SiO}_{2}$ & $\mathrm{Fe}_{2} \mathrm{O}_{3}$ & $\mathrm{SO}_{3}$ & $\mathrm{MgO}$ & $\begin{array}{c}\text { Glass } \\
\text { content }\end{array}$ \\
\hline $34.0 \%$ & $24.0 \%$ & $35.0 \%$ & $1.20 \%$ & $0.13 \%$ & $8.20 \%$ & $>90 \%$ \\
\hline
\end{tabular}

\section{LITERATURE REVIEW}

High strength concrete was prepared using foundry slag as a partial substitute for fine aggregate in varying proportions. Alccofine was used in an optimum amount of $15 \%$ as a partial substitute for Portland pozzolana cement. Results showed increase in Ultrasonic pulse velocity and rebound number with increase in foundry slag content and age [1]. Durability tests were conducted on high performance concrete made with Alccofine and Fly ash. Alccofine enhanced the durability of concretes and reduced the chloride diffusion. Due to the more compactness and less permeability of concrete, effect of chloride attack was reduced [2]. Strength and durability performance of concrete with Alccofine as partial replacement was studied and observed that $20 \%$ replacement of cement with Alccofine increased the strength and durability of concrete at all the ages [3]. The behavior of high performance of concrete with Alccofine as a supplementary cementitious material was studied. It was observed that $10 \%$ replacement of cement with Alccofine gave an increase in the compressive strength and flexural strength [4]. Performance of concrete was studied by replacing the cement with supplementary cementitious material Alccofine. Under sulphate attack, it was found that the weight loss decreased with the increase in Alccofine addition [5]. The behavior of Alccofine concrete was studied at different high range water reducing dosages with low water/binder ratios. The cost of concrete mix prepared with Alccofine was lesser than the concrete prepared without Alccofine [6]. Effect of elevated temperatures on compressive strength, Split tensile strength 
and Flexural strength was studied between the temperatures $50^{\circ} \mathrm{C}$ to $250^{\circ} \mathrm{C}$. Compressive strength, Split tensile strength and Flexural strength were found to be decreased with the increased temperature [7].

\section{EXPerimental Programme}

\section{A. Materials}

Cement, fine aggregate, coarse aggregate and water were used for the preparation of desired strength of concrete mix. In addition, Supplementary Cementitious Material (Alccofine 1203) was used to increase the strength of the concrete. Chemical admixture (ACE $30 \mathrm{JP}$ ) was also used to produce high workability in fresh concrete and to reduce water-cement ratio

\section{B. Cement}

Ordinary Portland Cement of 53 grade conforming to IS:8112-1989 was used in the present Project work. Specific gravity of cement was 3.10 and the cement was tested according to IS:1489-1991 (Part-I).

\section{Fine Aggregate}

Natural river sand was used as fine aggregate. Specific gravity of fine aggregate was 2.65. Fineness modulus is 2.87. Bulk density is $1778.26 \mathrm{~kg} / \mathrm{m}^{3}$. Testing of fine aggregate conforms to IS: $383-1970$.

\section{Coarse Aggregate}

Coarse aggregate passing through $20 \mathrm{~mm}$ sieve and retained on $10 \mathrm{~mm}$ sieve and $4.75 \mathrm{~mm}$ sieve was taken in $60 \%$ and $40 \%$ respectively. Specific gravity of Coarse aggregate was 2.70. Testing of coarse aggregate conforms to IS:383-1970.

\section{E. Water}

Potable water was used in the preparation of concrete. Water used conforms to IS:456-2000.

\section{F. Superplasticizer}

Superplasticizer used in the present study was Master Glenium BASF ACE30JP. Dosage of superplasticizer used was $1.27 \%$ by weight of binder. Chemical Admixture BASF ACE30JP is conforms to IS: 9103-1999.

\section{G. Mineral Admixture}

Alccofine1203 conforming to IS:12089-1987, IS:456-2000 (Clause No:5.2.2) and ASTM C989-99 [9] was used as a supplementary cementitious material. Its particle size is much finer than the cement particle size.

\section{H. Compressive Strength}

Mix proportions 1:0.556:1.629:0.25 and 1:0.617:1.644:0.25 were taken from the literature and trial castings were made to produce high strength concrete. Concrete cubes of $100 \mathrm{~mm} \times 100 \mathrm{~mm} \times 100 \mathrm{~mm}$ size were cast. Forty-eight hours after casting, cubes were demoulded and water cured for 28 days and tested using $3000 \mathrm{kN}$ Computerized Compression Testing Machine at right angle to the direction of casting for compressive strength of concrete as per IS: 516-1959 [10] as presented in Fig. 1.

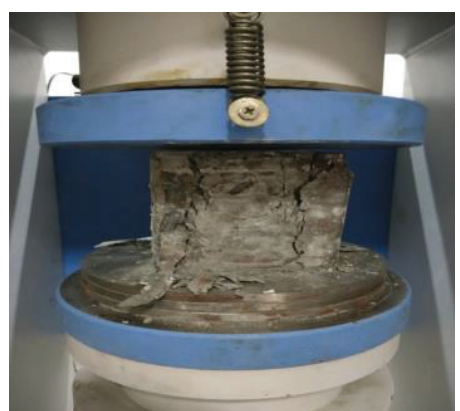

Figure 1. Cube testing under computerized Compression Testing Machine

Mix proportion 1:0.556:1.629:0.25 with 10\% Alccofine 1203 yielded high strength compared to $1: 0.617: 1.644: 0.25$ mix proportion. The results obtained from the compressive strength of concrete with mix proportions 1:0.556:1.629:0.25 was presented in Table III.

TABLE III.

Mix Proportions AND COMPRESSIVE STRENGTH DETAILS OF $1: 0.556: 1.629: 0.25$

\begin{tabular}{|c|c|c|}
\hline Mix Proportion & Alccofine 1203 & $\begin{array}{c}\text { Avg.Compressive } \\
\text { Strength (MPa) }\end{array}$ \\
\hline $1: 0.556: 1.629: 0.25$ & $5 \%$ & 69.71 \\
\hline $1: 0.556: 1.629: 0.25$ & $10 \%$ & 79.93 \\
\hline $1: 0.556: 1.629: 0.25$ & $15 \%$ & 63.55 \\
\hline
\end{tabular}

\section{Ultrasonic Pulse Velocity (UPV)}

In the present work, pulse velocity was measured on 100 mm cubes according to IS 13311 (Part 1):1992 [8] by using PUNDIT (Portable Ultrasonic Non-destructive Digital Indicating Tester) Lab plus apparatus as presented in Fig. 2. Higher velocities were obtained when the quality of concrete in terms of density, homogeneity and uniformity is good. In case of poorer quality, lower velocities are obtained. The test results before and after removing from high temperature furnace are presented in Fig. 3.

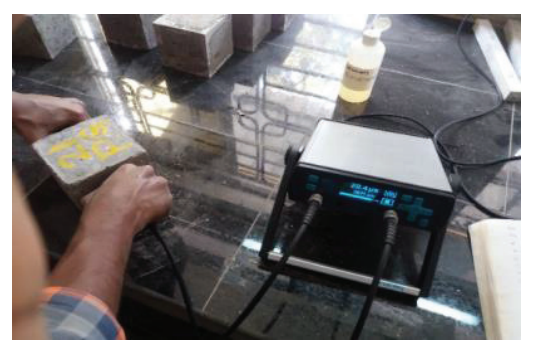

Figure 2. Ultrasonic Pulse velocity measurement of cubes

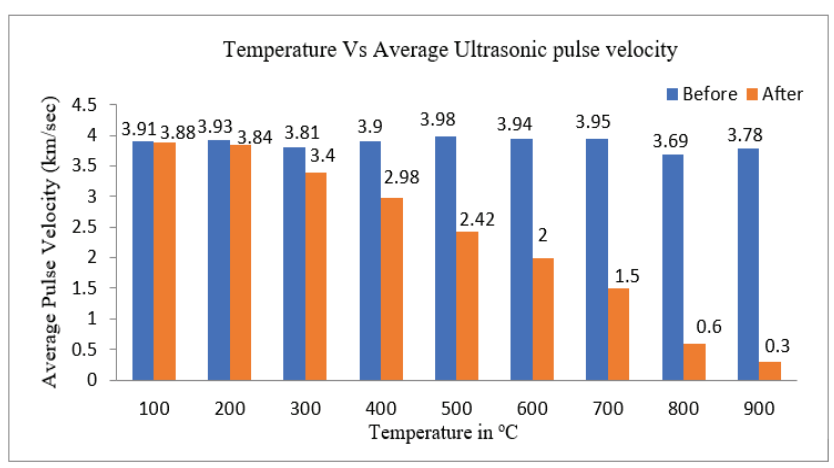

Figure 3. Average Ultrasonic pulse velocity of cubes before and after temperature studies. 


\section{J. Elevated Temperature Studies}

Fire accidents, sabotages or natural hazards are the situations where concrete is likely to get exposed to elevated temperatures. Exposure to elevated temperature causes Physical changes including large volume changes due to thermal dilations, thermal shrinkage and creep related to water loss. The volume changes can result in large internal stresses and lead to micro-cracking and fracture. Elevated temperatures also cause chemical and micro-structural changes such as water migration, increased dehydration, interfacial thermal incompatibility and the chemical decomposition of hardened cement past and aggregate. All these changes decrease the stiffness of concrete and increase the irrecoverable deformation.

In the present work, Cubes cast were kept in high temperature furnace for 02 hours duration at different temperatures from $100^{\circ} \mathrm{C}-900^{\circ} \mathrm{C}$ as presented in Fig .4. After 02 hours duration, cubes were taken out of the furnace and the Ultrasonic pulse velocity of cubes was measured using Portable Ultrasonic Non-destructive Digital Indicating Tester. The Percentage loss in weight of cubes and Residual compressive strength of the cubes were evaluated.

\section{K. Percentage loss in weight}

The percentage of weight loss of cubes after taking out from high temperature furnace is presented in Table IV.

TABLE IV.

Average Percentage of Weight Loss of Cubes after taking out FROM HIGH TEMPERATURE FURNACE

\begin{tabular}{|c|c|c|c|c|}
\hline $\begin{array}{c}\text { Temperature } \\
\left({ }^{\mathrm{O}} \mathrm{C}\right)\end{array}$ & $\begin{array}{l}\text { Specimen } \\
\text { designation }\end{array}$ & $\begin{array}{c}\text { Weight } \\
\text { of } \\
\text { specimen } \\
\text { before } \\
\text { placing } \\
\text { in HTF } \\
\text { (W1) } \\
\text { kg }\end{array}$ & $\begin{array}{l}\text { Weight } \\
\text { of } \\
\text { specimen } \\
\text { after } \\
\text { taking } \\
\text { out from } \\
\text { HTF } \\
\text { (W2) } \\
\text { kg }\end{array}$ & $\begin{array}{c}\text { Average } \\
\text { percentage } \\
\text { of weight } \\
\text { loss = } \\
((\mathrm{W} 1- \\
\text { W2 })^{*} \\
100) / \mathrm{W} 1\end{array}$ \\
\hline \multirow[t]{3}{*}{100} & $10 \mathrm{BT}$ & 2.41 & 2.40 & \multirow[b]{3}{*}{1.63} \\
\hline & $18 \mathrm{BT}$ & 2.46 & 2.36 & \\
\hline & $19 \mathrm{BT}$ & 2.48 & 2.47 & \\
\hline \multirow[t]{3}{*}{200} & $2 \mathrm{BT}$ & 2.55 & 2.50 & \multirow[b]{3}{*}{2.02} \\
\hline & $3 \mathrm{BT}$ & 2.41 & 2.35 & \\
\hline & $24 \mathrm{BT}$ & 2.46 & 2.41 & \\
\hline \multirow[t]{3}{*}{300} & $6 \mathrm{BT}$ & 2.49 & 2.40 & \multirow[b]{3}{*}{4.06} \\
\hline & $20 \mathrm{BT}$ & 2.44 & 2.33 & \\
\hline & $22 \mathrm{BT}$ & 2.45 & 2.35 & \\
\hline \multirow[t]{3}{*}{400} & $1 \mathrm{BT}$ & 2.46 & 2.33 & \multirow[b]{3}{*}{5.28} \\
\hline & $12 \mathrm{BT}$ & 2.45 & 2.32 & \\
\hline & $25 \mathrm{BT}$ & 2.47 & 2.35 & \\
\hline \multirow[t]{3}{*}{500} & $7 \mathrm{BT}$ & 2.41 & 2.27 & \multirow[b]{3}{*}{5.73} \\
\hline & $17 \mathrm{BT}$ & 2.47 & 2.35 & \\
\hline & $21 \mathrm{BT}$ & 2.45 & 2.30 & \\
\hline \multirow[t]{3}{*}{600} & $9 \mathrm{BT}$ & 2.47 & 2.33 & \multirow[b]{3}{*}{6.09} \\
\hline & $23 \mathrm{BT}$ & 2.46 & 2.29 & \\
\hline & $26 \mathrm{BT}$ & 2.47 & 2.32 & \\
\hline \multirow[t]{3}{*}{700} & $11 \mathrm{BT}$ & 2.49 & 2.32 & \multirow[b]{3}{*}{6.45} \\
\hline & $15 \mathrm{BT}$ & 2.46 & 2.33 & \\
\hline & $4 \mathrm{BT}$ & 2.49 & 2.32 & \\
\hline \multirow[t]{3}{*}{800} & $13 \mathrm{BT}$ & 2.43 & 2.25 & \multirow[b]{3}{*}{6.93} \\
\hline & $16 \mathrm{BT}$ & 2.48 & 2.33 & \\
\hline & $27 \mathrm{BT}$ & 2.44 & 2.27 & \\
\hline \multirow[t]{3}{*}{900} & $8 \mathrm{BT}$ & 2.50 & 2.32 & \multirow[b]{3}{*}{7.22} \\
\hline & $73 \mathrm{BT}$ & 2.48 & 2.30 & \\
\hline & $77 \mathrm{BT}$ & 2.50 & 2.33 & \\
\hline
\end{tabular}

The percentage loss in weight of cubes was found to be increased up to $900^{\circ} \mathrm{C}$. It was observed that there was an increase in percentage of weight loss with respect to increase in temperature.

\section{Compressive Strength}

The compressive Strength of cubes before placing and after removing from high temperature furnace are presented in Table V.

TABLE V.

COMPRESSIVE STRENGTH OF Cubes SubJeCted to EleVATED TEMPERATURE STUDIES

\begin{tabular}{|c|c|c|c|}
\hline $\begin{array}{c}\text { Temperature } \\
\left({ }^{\mathrm{O}} \mathrm{C}\right)\end{array}$ & $\begin{array}{c}\text { Average } \\
\text { compressive } \\
\text { strength } \\
\text { before } \\
\text { placing in } \\
\text { HTF (MPa) }\end{array}$ & $\begin{array}{c}\text { Average } \\
\text { residual } \\
\text { compressive } \\
\text { strength after } \\
\text { taking out from } \\
\text { HTF }(\mathrm{MPa})\end{array}$ & $\begin{array}{c}\text { Average } \\
\text { percentage } \\
\text { loss in } \\
\text { compressive } \\
\text { strength }\end{array}$ \\
\hline 100 & 78.06 & 63.06 & 19.34 \\
\hline 200 & 78.69 & 56.93 & 27.72 \\
\hline 300 & 77.55 & 91.9 & -18.55 \\
\hline 400 & 78.86 & 68.3 & 11.74 \\
\hline 500 & 77.39 & 62.1 & 19.71 \\
\hline 600 & 78.52 & 57.4 & 26.809 \\
\hline 700 & 77.83 & 52.76 & 32.15 \\
\hline 800 & 77.98 & 37.36 & 52.06 \\
\hline 900 & 79.44 & 23.96 & 69.83 \\
\hline
\end{tabular}

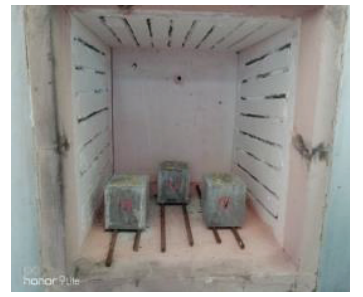

Figure 4. Cubes in High High Temperature Furnace

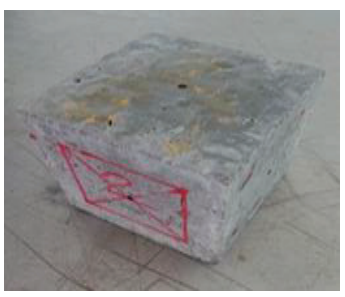

Figure 6(a). Cube after $02 \mathrm{hrs}$ in High Temperature Furnace at $200^{\circ} \mathrm{C}$

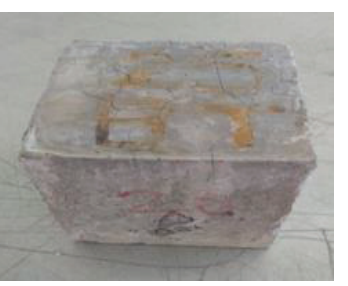

Figure 7(a). Cube after $02 \mathrm{hrs}$ in High Temperature Furnace at $400^{\circ} \mathrm{C}$

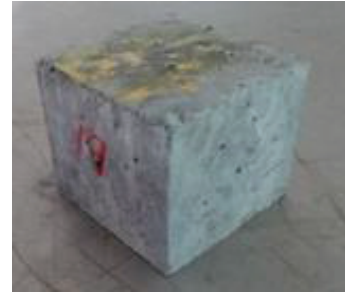

Figure 5. Cube after $02 \mathrm{hrs}$.in Temperature Furnace at $100^{\circ} \mathrm{C}$

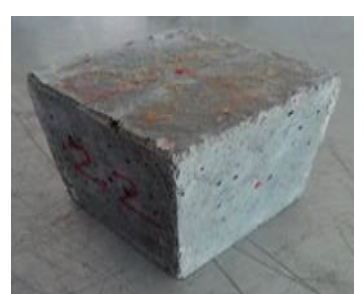

Figure 6(b). Cube after $02 \mathrm{hrs}$. in High Temperature Furnace at $300^{\circ} \mathrm{C}$

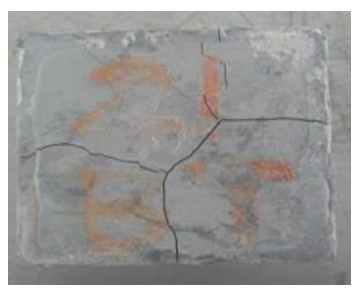

Figure 7(b). Cube after 02 hrs. in High Temperature Furnace at $500^{\circ} \mathrm{C}$ 


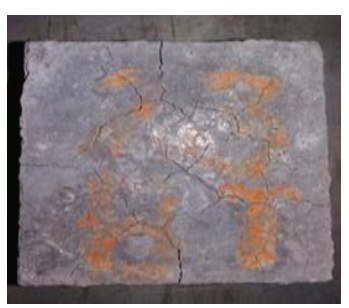

Figure 8(a). Cube after 02 hrs. in High Temperature Furnace at $600^{\circ} \mathrm{C}$

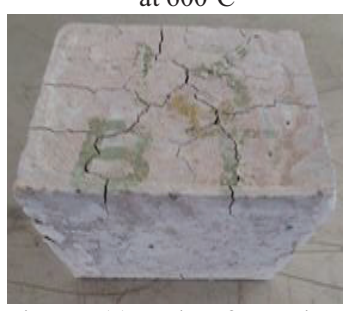

Figure 9(a). Cube after 02 hrs. in High Temperature Furnace at $800^{\circ} \mathrm{C}$

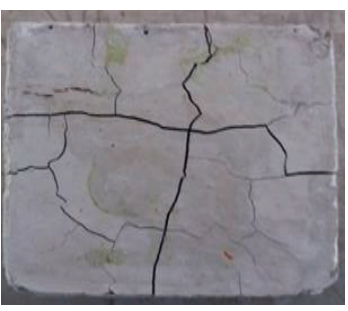

Figure 8(b). Cube after 02 hrs in High Temperature Furnace at $700^{\circ} \mathrm{C}$

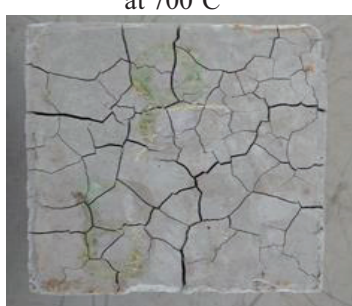

Figure 9(b). Cube after 02 hrs in High Temperature Furnace at $900^{\circ} \mathrm{C}$

No visible cracks and spalling were found up to $300^{\circ} \mathrm{C}$ as presented in Fig. 5, Fig. 6(a) and Fig. 6(b) respectively. Cracks were observed in the specimens tested to $400^{\circ} \mathrm{C}$ and $500^{\circ} \mathrm{C}$ as presented in Fig. 7(a) and Fig. 7(b). Cracks were observed as pronounced in the specimens subjected to $600^{\circ} \mathrm{C}, 700^{\circ} \mathrm{C}, 800^{\circ} \mathrm{C}$ and $900^{\circ} \mathrm{C}$ respectively as presented Fig. 8(a), Fig.8(b), Fig. 9(a) and Fig.9(b) respectively. Above $700^{\circ} \mathrm{C}$, large crack widths and depths were observed in the specimens. The variation in color was observed with respect to the temperature increase. $\mathrm{Up}$ to $600^{\circ} \mathrm{C}$, the concrete colour doesn't change noticeably. When the temperature was increased to $700^{\circ} \mathrm{C}$, the color of cube was changed from normal to pink or red as presented in Fig. 8(b). When the temperature was increased above $700^{\circ} \mathrm{C}$, the color of cube was changed to whitish grey as presented in Fig. 9(b).

\section{Durability Studies - Sulphate Attack Test}

Sulphate attack test was carried out on $100 \mathrm{~mm}$ x100 mm x $100 \mathrm{~mm}$ concrete cubes. Total 03 cubes were casted and cured in water for 28 days. After 28 days curing, cubes were taken out and allowed for drying for 24 hours at $50^{\circ} \mathrm{C}$ and weights were taken before placing in the sulphate solution $\left(2.5 \% \mathrm{Na}_{2} \mathrm{SO}_{4}\right.$ and $2.5 \% \mathrm{MgSO}_{4}$ by weight of water) as presented in Fig. 10. The concentration of the solution was maintained throughout this period by changing the solution periodically. The specimens were taken out from the sulphate solution after the prescribed period of continuous soaking and the surface of the cubes was cleaned, weighed $\&$ the average percentage of loss in weight was calculated at 7, 14, 28 and 56 days as presented in Fig. 11 and tested in the compressive testing machine at the end of 56 days and the compressive strength of the concrete cubes was calculated as per IS: 516-1959 [10].

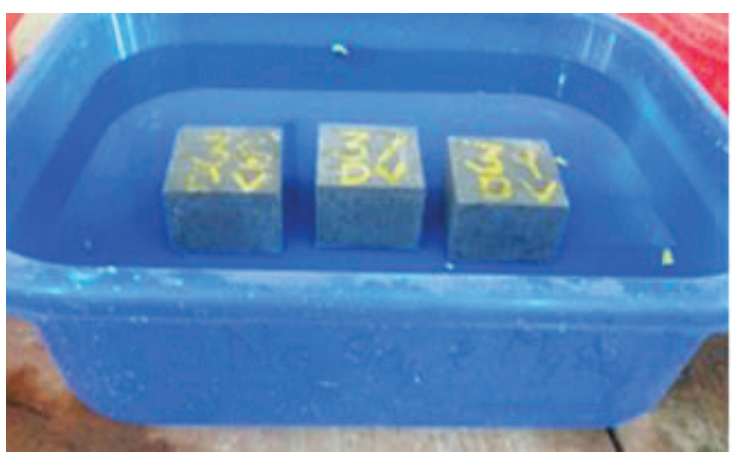

Figure 10. Cubes immersed in $\mathrm{MgSo}_{4} \& \mathrm{Na}_{2} \mathrm{So}_{4}$

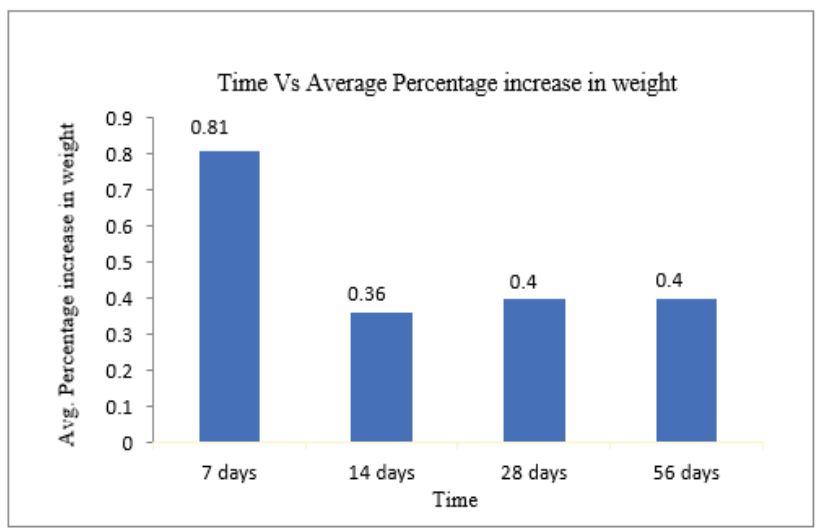

Figure 11. Variation of average percentage increase in weight of cubes taken out from $\mathrm{MgSO}_{4}$ and $\mathrm{Na}_{2} \mathrm{SO}_{4}$

\section{N. Chloride Attack Test}

Chloride resistance test was carried out on $100 \mathrm{~mm} \times 100$ $\mathrm{mm}$ x100 mm concrete cubes. Total 03 cubes were casted and cured in water for 28 days. After 28 days curing, cubes were taken out and allowed for drying for 24 hours at $50^{\circ} \mathrm{C}$ and weights were taken before placing in the sodium chloride solution ( $5 \%$ of Nacl by weight of water) as presented in Fig. 12. The concentration of the solution was maintained throughout this period by changing the solution periodically. The specimens were taken out from the sodium chloride solution after the prescribed period of continuous soaking and the surface of the cubes was cleaned, weighed $\&$ the average percentage of loss in weight was calculated at 7, 14, 28 and 56 days as presented in Fig. 13 and tested in the compressive testing machine at the end of 56 days and the compressive strength of the concrete cubes was calculated as per IS: 516-1959.

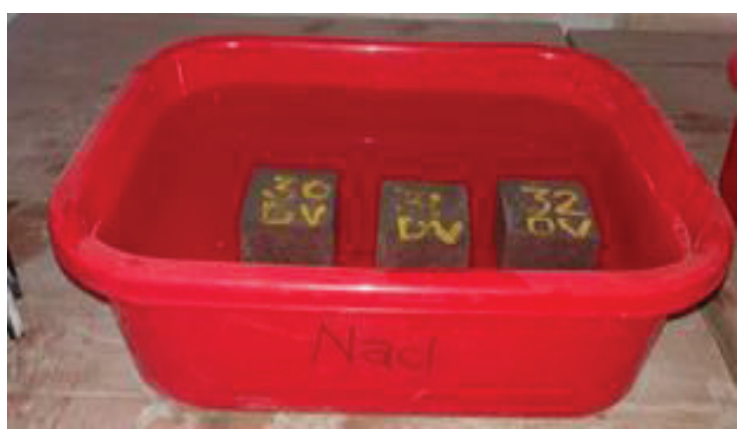

Figure 12. Cubes immersed in Nacl 


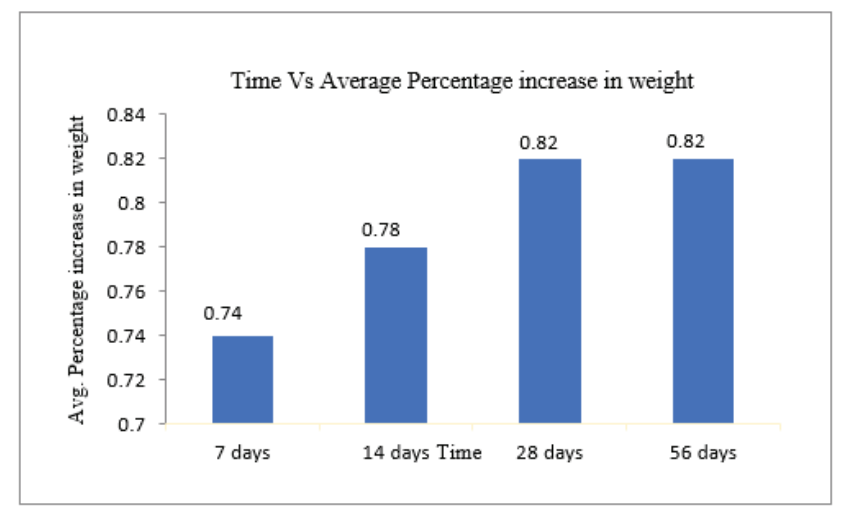

Figure 13. Variation of average percentage increase in weight of cubes

\section{O. Alkali Attack Test} taken out from Nacl

Alkali attack test was carried out on $100 \mathrm{~mm}$ x100 mm x100 mm concrete cubes. Total 03 cubes were casted and cured in water for 28 days. After 28 days curing, cubes were taken out and allowed for drying for 24 hours at $50^{\circ} \mathrm{C}$ and weights were taken before placing in the sodium hydroxide solution $(5 \%$ of sodium hydroxide solution by weight of water) as presented in Fig.14. The concentration of the solution was maintained throughout this period by changing the solution periodically. The specimens were taken out from the sulphate solution after the prescribed period of continuous soaking and the surface of the cubes was cleaned, weighed $\&$ the average percentage of loss in weight was calculated at $7,14,28$ and 56 days as presented in Fig. 15 and tested in the compressive testing machine at the end of 56 days and the compressive strength of the concrete cubes was calculated as per IS: 516-1959.

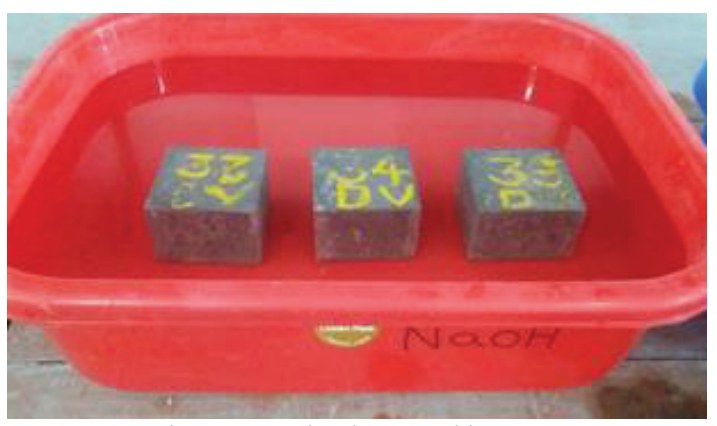

Figure 14. Cubes immersed in $\mathrm{NaOH}$

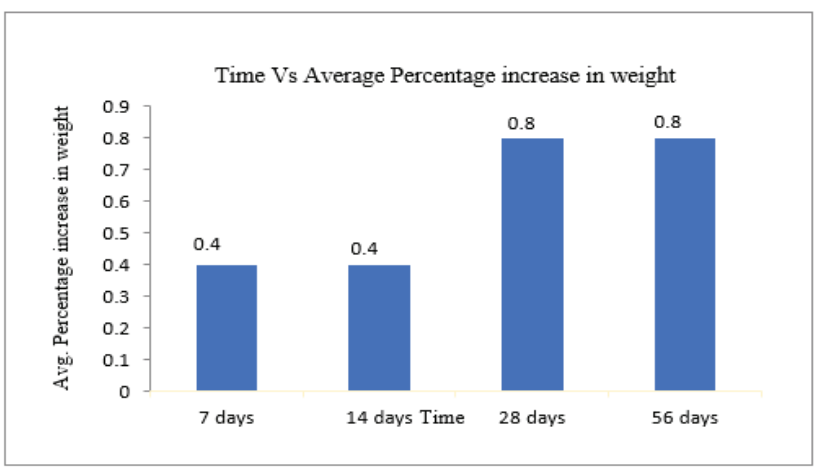

Figure 15. Variation of average percentage increase in weight of cubes taken out from $\mathrm{NaOH}$

\section{P. Sea Water Test}

Sea water was brought from Bay of Bengal and test was carried out on $100 \mathrm{~mm} \times 100 \mathrm{~mm} \times 100 \mathrm{~mm}$ concrete cubes. Total 03 cubes were casted and cured in water for 28 days. After 28 days curing, cubes were taken out and allowed for drying for 24 hours at $50^{\circ} \mathrm{C}$ and weights were taken before placing in the sea water ( $5 \%$ of Sea water solution) as presented in Fig.16. The concentration of the solution was maintained throughout this period by changing the solution periodically. The specimens were taken out from the sulphate solution after the prescribed period of continuous soaking and the surface of the cubes was cleaned, weighed $\&$ the average percentage of loss in weight was calculated at 7, 14, 28 and 56 days as presented in Fig.17 and tested in the compressive testing machine at the end of 56 days and the compressive strength of the concrete cubes was calculated as per IS: 516-1959.

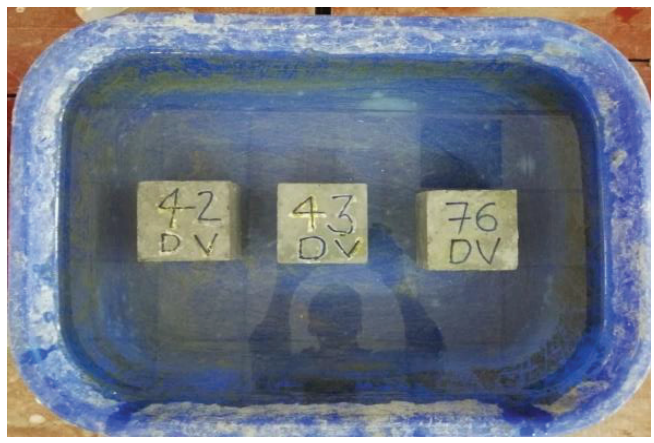

Figure 16. Cubes immersed in Sea Water

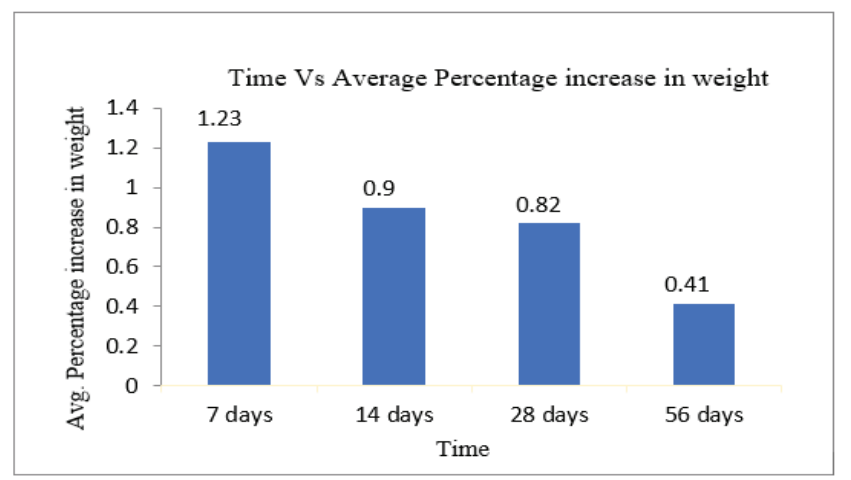

Figure 17. Variation of average percentage increase in weight of cubes taken out from Sea Water

\section{Q. Percentage Increase in Weight}

The Percentage increase in weight for $\mathrm{Nacl}, \mathrm{NaoH}, \mathrm{MgSo}_{4}$ $\& \mathrm{Na}_{2} \mathrm{So}_{4}$ and Sea Water as presented in Fig. 18 .

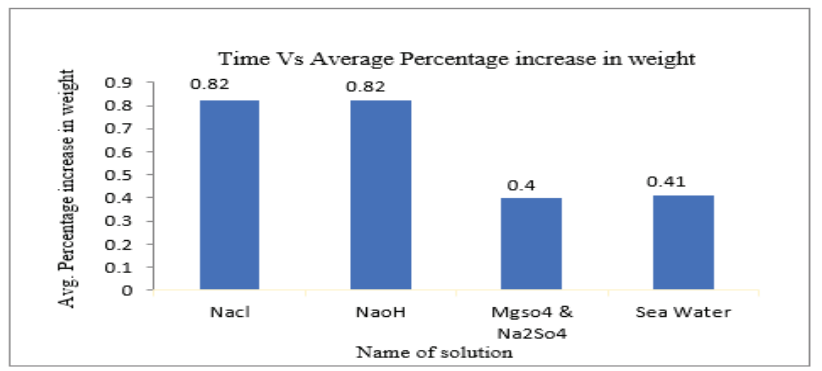

Figure 18. Comparison of percentage Increase in weight of cubes for different solutions at 56 days 


\section{R. Compressive Strength}

The Average Compressive Strength before placing and after removing from $\mathrm{Nacl}, \mathrm{NaOH}, \mathrm{MgSo}_{4} \& \mathrm{Na}_{2} \mathrm{So}_{4}$ and Sea Water and percentage increase in compressive strength are presented in Table 6.

TABLE VI.

Percentage InCREAse in Compressive Strength of Cubes at 56 DAYS

\begin{tabular}{|c|c|c|c|}
\hline $\begin{array}{c}\text { Name of } \\
\text { Solution }\end{array}$ & $\begin{array}{c}\text { Average } \\
\text { Compressive } \\
\text { Strength when } \\
\text { cured in potable } \\
\text { water } \\
(\mathrm{MPa})\end{array}$ & $\begin{array}{c}\text { Average } \\
\text { Compressive } \\
\text { Strength after taking } \\
\text { out from the } \\
\text { chemical solutions } \\
\text { (at 56days) } \\
(\mathrm{MPa})\end{array}$ & $\begin{array}{c}\text { Percentage } \\
\text { Increase in } \\
\text { Compressive } \\
\text { strength }\end{array}$ \\
\hline $\mathrm{Nacl}$ & 69.71 & 91.83 & 31.73 \\
\hline $\mathrm{NaOH}^{\mathrm{MgSo}}+$ & 79.93 & 94.6 & 18.35 \\
\hline $\mathrm{Na}_{2} \mathrm{So}_{4}$ & 63.55 & 86.93 & 36.78 \\
\hline $\mathrm{Sea} \mathrm{Water}^{\mathrm{Nea}}$ & 78.40 & 89.10 & 13.64 \\
\hline
\end{tabular}

\section{S. Sorptivity Test}

Sorptivity is the absorption and transmission of water through capillary action.

Before the specimen is placed in contact with water it was kept in oven at temperature of $50^{\circ} \mathrm{C}$ for 03 days [9]. Cubes $(10 \mathrm{~cm})$ were placed as presented in Fig. 19.

The absorption (I) due to capillary action is the change in mass divided by the product of the cross-sectional area of the test specimen and the density of water as in (1). The units of 'I' are mm.

$$
I=\left(\frac{m_{t}}{a * d}\right)
$$

Where, I = absorption

$\Delta \mathrm{W}=$ change in weight $=\mathrm{W} 2-\mathrm{W} 1$

$\mathrm{W} 1=$ Oven dry weight of cube in grams

$\mathrm{W} 2=$ Weight of cube after the prescribed time

due to capillary suction of water in grams.

$\mathrm{m}_{\mathrm{t}}=$ change in specimen mass (in grams, at time $\mathrm{t}$ )

$\mathrm{a}=$ exposed area of the specimen through which water penetrated $\left(\mathrm{mm}^{2}\right)$

$\mathrm{d}=$ density of the water $\left(\mathrm{g} / \mathrm{mm}^{3}\right)$

Sorptivity was calculated using the expression presented in (2).

$$
\text { Sorptivity, } \mathrm{S}=\mathrm{I} / \mathrm{t}^{1 / 2}
$$

Where, $\mathrm{S}=$ Sorptivity in $\mathrm{mm} / \mathrm{min}^{1 / 2}$ $\mathrm{t}=$ elapsed time in $\min$.

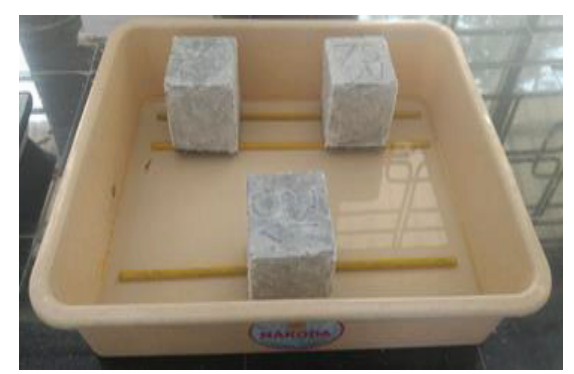

Figure 19. Cubes under Sorptivity test
Sorptivity coefficient is calculated as $1.5873 \times 10^{-4}$ $\mathrm{mm} / \mathrm{min}^{0.5}$ from the graph presented in Fig. 20 .

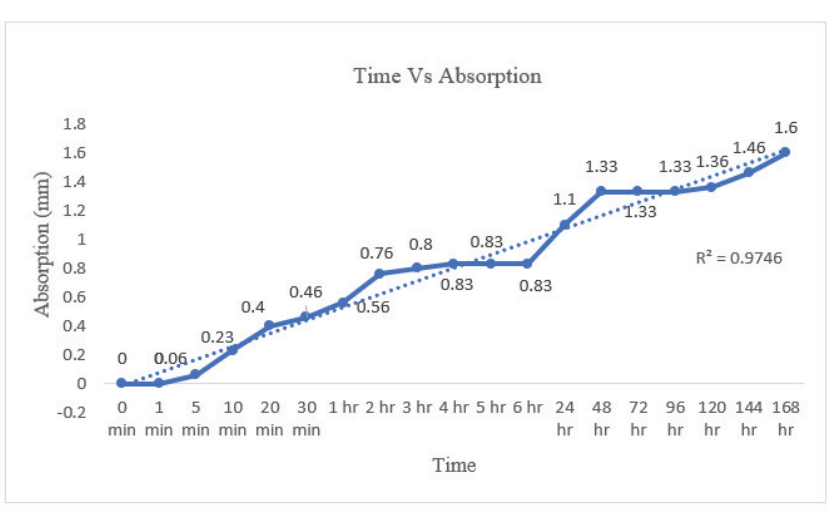

Figure 20. Variation of water absorption of cubes with respect to time

\section{Discussions AND CONCLUSIONS}

The quality category of cubes before temperature studies as per IS:13311 (Part-I) was 'Good'. The Ultrasonic pulse velocity of high strength concrete cubes as per IS:13311 (Part-I) between $100^{\circ} \mathrm{C}-900^{\circ} \mathrm{C}$ in an interval of $100^{\circ} \mathrm{C}$ was found to be 'Good' quality for $100^{\circ} \mathrm{C}, 200^{\circ} \mathrm{C}$ and 'Medium' quality for $300^{\circ} \mathrm{C}$ and 'Doubtful' quality for $400^{\circ} \mathrm{C}, 500^{\circ} \mathrm{C}$, $600^{\circ} \mathrm{C}, 700^{\circ} \mathrm{C}, 800^{\circ} \mathrm{C}$ and $900^{\circ} \mathrm{C}$. Due to the weakened cohesion between the mixture constituents, path length of the Ultrasonic pulse velocity might have been increased and thereby decreasing the velocity. This might be the reason for the decrease in quality category of concrete cubes from 'Good' to 'Doubtful'.

The effect of elevated temperatures on weight of concrete cubes was studied between $100^{\circ} \mathrm{C}-900^{\circ} \mathrm{C}$ in an interval of $100^{\circ} \mathrm{C}$. The percentage loss in weight of cubes was found to be increased from $100^{\circ} \mathrm{C}$ to $900^{\circ} \mathrm{C}$. This may be attributed to the continuous evaporation of moisture from the concrete cubes which might have weakened the bonding between the binder and the course aggregate.

The percentage difference in compressive strength between $100^{\circ} \mathrm{C}$ to $900^{\circ} \mathrm{C}$ in an interval of $100^{\circ} \mathrm{C}$ was $19.34,27.72$, $18.55,11.74,19.71,26.80,32.15,52.06,69.83$. The increase in strength at $300^{\circ} \mathrm{C}$ might be attributed to the increase in surface forces between gel particles (Vander Waal forces) due to the removal of moisture content. The decrease in compressive strength at $800^{\circ} \mathrm{C}$ may be attributed to decomposition of the cementing compound C-S-H with its different phases, dehydration of calcium hydroxide $(\mathrm{CH})$ into free lime. These changes would have affected the volume occupied by these cementitious products and when combined with the weakened cohesion between the mixture constituents due to the different expansions experienced by each of them. The decrease in compressive strength at $900^{\circ} \mathrm{C}$ may be attributed to the decomposition of calcium carbonate through the loss of $\mathrm{CO}_{2}$ and all the free water might have lost.

The percentage variation in average weight of $10 \mathrm{~cm}$ concrete cubes after 56 days of immersion in Nacl solution, $\mathrm{NaoH}$ solution, $\mathrm{MgsO}_{4}$ plus $\mathrm{Na}_{2} \mathrm{SO}_{4}$ solution and Sea water was found to be $0.82,0.80,0.40$ and 0.41 respectively. The percentage variation in weight of cubes is very less and this might be due to the error in taking the measurements. 
The percentage increase in compressive strength after taking out from the chemical solutions $\mathrm{Na}_{2} \mathrm{SO}_{4}$ and $\mathrm{MgSO}_{4}$, $\mathrm{Nacl}, \mathrm{NaoH}$ and Sea water at 56 days was found to be 31.73, $18.35,36.78$ and 13.64 respectively. The concentration of these solutions was not sufficient enough to affect the Compressive strength of concrete cubes.

More absorption of water due to capillary action might be attributed to the precondition of the concrete cubes at a temperature of $50^{\circ} \mathrm{C}$ for 03 days as per ASTM:C1585-04.

Based on the above discussions, the use of Alccofine 1203 is recommended as a mineral admixture to prepare a concrete of high strength and durability.

\section{REFERENCES}

[1] Devinder Sharma, Sanjay Sharma, Ajay Goyal,"Pre-diction of High Compressive Strength of Concreteusing Waste Foundry Slag and Alccofine by NDT,'International Journal of Engineering Research \&Tech-Nology, ISSN: 2278-0181, vol.5, Issue 02, February-2016.

[2] Yatin, H., Patel, Patel, P.J., Jignesh, M., Patel, Patel, H.S., "Study on Durability of High PerformanceConcrete with Alccofine and Fly Ash," International Journal of Advanced Engineering Research and Studies, E-ISSN:2249- 8974, vol 2, Issue 03, April-June-2013.

[3] Narender, A., Reddy, Meena, T., "A Comprehensive Overview on Performance of Alcco fine Concrete," International Journal of Pharmacy \& Technology, ISSN: 0975-766X, vol 9, Issue 01, April-2017.

[4] Vikram, K., Shadi, Banarase, M.A., "Experimental Study on Effect of Alccofine on Properties of Concrete- A Review," International Journal of Research in Engineering, Science and Technologies, ISSN: 23956453, vol 1, Number 8, December-2015.

[5] Gayathri, K., Ravichandran, K., Saravanan, J., "Durability and Cementing Efficiency of Alccofine in Concretes," International Journal of Research in Engineering and Technology, ISSN: 2278-0181, vol 5, Issue 05, May-2016.

[6] Saurabh Gupta, Sanjay Sharma, Devinder, E.R., Sharma, "A Review on Alccofine: A Supplementary Cementitious Material," International Journal of Modern Trends in Engineering and Research, ISSN: 2349-9745, vol 2, Issue 08, August-2015.

[7] Sreenivasulu, A., Srinivasa, K., Rao, "The Effect of Temperature on Mechanical Properties of M100 Concrete,' American Journal of Engineering Research, ISSN: 2320-0847, Vol 02, Issue 04, 2013.

[8] IS 13311 (Part 1): 1992 -Non-Destructive Testing of Concrete-Methods of Test (Part 1 Ultrasonic Pulse Velocity).

[9] ASTM: C1585-04, "Standard Test Method for Measurement of Rate of Absorption of Water by Hydraulic Cement Concretes", PP 1-5.

[10] IS :516-1959, "Method of Tests for Strength of Concrete, Bureau of Indian Standards. 